\title{
An Assessment of Vehicular Emission in the Vicinity of Selected Markets in Owerri, Imo State, Nigeria
}

\author{
Bridget Diagi', Ajiere Suzan², Okorondu Nnaemeka1, Chinonye Ekweogu', \\ Chidinma Acholonu'1, Obanaka Emmanuel ${ }^{1}$ \\ ${ }^{1}$ Department of Environmental Management, Federal University of Technology, Owerri, Nigeria \\ ${ }^{2}$ Department of Geography and Environmental Management, University of Port Harcourt, Port Harcourt, Nigeria \\ Email: edeoli@yahoo.com
}

How to cite this paper: Diagi, B., Suzan, A., Nnaemeka, O., Ekweogu, C., Acholonu, C., \& Emmanuel, O. (2022). An Assessment of Vehicular Emission in the Vicinity of Selected Markets in Owerri, Imo State, Nigeria. Journal of Geoscience and Environment Protection, 10, 1-12. https://doi.org/10.4236/gep.2022.101001

Received: October 30, 2021

Accepted: January 4, 2022

Published: January 7, 2022

Copyright $\odot 2022$ by author(s) and Scientific Research Publishing Inc. This work is licensed under the Creative Commons Attribution International License (CC BY 4.0).

http://creativecommons.org/licenses/by/4.0/

\begin{abstract}
This study assessed pollutants concentration at selected markets in Owerri. These markets were purposively selected after careful consideration of all major markets in the study area; the selected markets were considered to be more congested during the day as a result of open assess to road junctions coupled with a high density of vehicular movement, presence of offices, residential buildings, and human activities. Five air pollutants from vehicular emissions were monitored, namely: carbon monoxide (CO), carbon dioxide $\left(\mathrm{CO}_{2}\right)$, nitrogen dioxide $\left(\mathrm{NO}_{2}\right)$, particulate matter (PM 2.5) and particulate matter (PM 10). Assessments were carried out within 3 hours per dual diurnal section using approved standard methods which were converted to a 1-hour mean for the morning and afternoon period of sampling 7-10 am and 2-5 pm. These periods are known for the peak of human and vehicular movement within the study area. Results show that the highest level of CO concentration (0.293 - $0.387 \mathrm{ppm})$ was recorded at Alaba market and is less than the permissible limit of $35 \mathrm{ppm}$ given by national ambient air quality standard (NAAQS). The highest range of $\mathrm{CO}_{2}(1153$ - $1875 \mathrm{ppm})$ was recorded from Alaba market which is higher than the ambient standard of 314 $\mathrm{ppm}$. The highest level of $\mathrm{NO}_{2}(0.116-0.297 \mathrm{ppm})$ was recorded from Relief market which is also higher than the permissible limit $(0.100 \mathrm{ppm})$ of NAAQS. The highest range of particulate matter of PM 2.5 and PM 10 was recorded from Relief market $\left(0.011-0.029 \mu \mathrm{g} / \mathrm{m}^{3}\right)$ and $\left(0.065-0.172 \mu \mathrm{g} / \mathrm{m}^{3}\right)$ respectively and is far lower than the permissible limit $\left(150 \mu \mathrm{g} / \mathrm{m}^{3}\right)$ of NAAQS and WHO (base on target 1) standards. The study, therefore, concludes that there is a significant impact of emission from vehicles in the selected markets in Owerri metropolis as result indicates a high risk of health
\end{abstract}


problems in the markets due to the high level of $\mathrm{CO}_{2}$ and $\mathrm{NO}_{2}$. It, therefore, recommends that an adequate mechanism should be put in place to decongest traffic density in the city especially near markets so as to have a substantial reduction in vehicular emissions and improve the livability of the citizens.

\section{Keywords}

Assessment, Vehicular Emission, Markets, Owerri, Nigeria

\section{Introduction}

Environmental problems constitute one of the key challenges of the $21^{\text {st }}$ century, and urban air pollution is a major health hazard worldwide. Man-made activities resulting from human quest to generate returns for survival have increased the rate of pollutants emissions within the earth's atmosphere (David et al., 2019). Air pollution comes mainly from four main sources namely; vehicular emissions, industrial activities, domestic cooking, and tobacco smoking. Nevertheless, the level of air pollution depends on a country's technological advancement and pollution control measures (Nkwocha et al., 2017). Owerri, the capital city of Imo State is one of fast-growing cities in the South East of Nigeria (Chukwuocha et al., 2016; Okonkwo et al., 2019). It is a hub of economic, social and political development as well as industry and commerce activity (Aliyu \& Amadu, 2017) as a result of this development, there is a continuous inflow of people into the city of Owerri in search of greener pastures (Omenikolo et al., 2017). With rising incomes levels, this human influx combined with an increasing desire for personal movement and travel has led to a pronounced increase in automobile ownership and transportation. Thereby, causing an increase in the number of motor vehicles on the major roads, within the city of Owerri, which cumulatively contribute to degrading the air due to the emissions from exhaust of these motor vehicles (Muralikrishnan et al., 2014; Zagha \& Nwaogazie, 2015). Over the years, commercial transportation within the city of Owerri has gone through several transitions; from the use of motorcycles to tricycles popularly known as Keke Napep and recently, the use of mini buses for commercial transport within the city (Achonu, 2017; Alozie, 2017). The numerous opportunities found in the city encourage different types of activities of which traffic usage is central. Most roads in Owerri metropolis are in very bad condition and lack the capability to accommodate the volume of increased vehicular movement thereby resulting in congestion which could have been avoided.

This phenomenon causes delay resulting in emission concentration within the areas. Energy to power vehicle comes from the combustion of fuel gas (Oguntoke \& Yussuf, 2008) during the process of combustion, exhaust gases are released into the environment. In a study carried out by (Mmom \& Essiet, 2014), it was asserted that automobiles transiting major urban regions in Nigeria are projected to account for $80 \%$ of all carbon monoxide, $50 \%$ of hydrocarbons and about $40 \%$ of 
oxides of nitrogen. Research has shown that emission from vehicles in Nigeria is higher in the morning, within break time (during the afternoon) and in the evening (Oguntoke \& Yussuf, 2008; Mmom \& Essiet, 2014; Okunola et al., 2012). This is as a result of the traffic jam experienced during these peak periods. Exposures of living organisms including humans to these emissions can lead to short and long term injurious health complications.

However, this does not seem to bother both the emitters and environmental regulators (David et al., 2019) due to lack of insensitivity on their part to the danger posed by the continuous emission of these pollutants to the environment. Out of the different kinds of environmental pollution taking place in urban markets, vehicular emission is one of the major environmental challenges that has bedeviled both the developed and developing countries of the world today (Ibe et al., 2017). Motor vehicles in developing countries cause serious air pollution due to their concentration in a few large cities, besides, many are in poor mechanical conditions since they are mostly second hand vehicles imported from other countries. Vehicular emissions are expected to increase reasonably as automobile ownership increase globally (Abam \& Unachukwu, 2015) Vehicle exhaust generally emits poly cyclic aromatic hydrocarbons (PAHs), particulate matters, carbon monoxide ( $\mathrm{CO})$, nitrogen oxides (NOx) and volatile organic compounds (VOCs) such as benzene. Emission from vehicles has continued to draw a lot of attention from the research community as well as concerned citizens in the global community as a result of its negative impacts on the environment and the general wellbeing of man (Njoku et al., 2016; Xie et al., 2017; Ngele \& Onwu, 2014; Olayinka et al., 2015; Etim, 2016; Ude et al., 2016; Chukwuocha et al. 2016; Ipeaiyeda \& Adegbooyega, 2017; Ugbebor \& LongJohn, 2018; Chakraborty et al., 2020; Ogungbe et al., 2019 \& Houston et al., 2004).

Rapid population growth in cities, industrialization, development and intensification of markets pose significant challenges to ambient air quality through vehicular emissions (Mauss, 2017). Poor urban air quality is traceable to toxic criteria air pollutants according to the US Clean Air Act of 1970 (Suh et al., 2017). The rapid increase in the use of vehicles for day to day transportation in most developing countries, coupled with a lack of emission standards in these countries, has contributed a great deal of concern over vehicular pollution (Mauss, 2017; Suh et al., 2017). Vehicular emission is at its peak when there is an increase in population, together with increase in the number of vehicles on roads (Omenikolo et al., 2017). Six air pollutants which are designated as criteria pollutants are Sulphur dioxide $\left(\mathrm{SO}_{2}\right)$, nitrogen dioxide $\left(\mathrm{NO}_{2}\right)$, carbon monoxide $(\mathrm{CO})$, ozone $\left(\mathrm{O}_{3}\right)$, particulate matter with aerodynamic diameters under 10 and $2.5 \mu \mathrm{m}$, as well as lead. These are regarded as criteria pollutants because they are strongly suspected to be harmful to public health and the environment.

Consequently, in urban areas, vehicular emission is one of the largest contributing factors to air pollution. In addition, a multitude of air contaminants of varying toxicity comes from road transport (Roychowdhury et al., 2016). According to (Aliyu \& Amadu, 2017), pollution due to road traffic constitutes $80 \%$ 
- 90\% of nitrogen oxides $\left(\mathrm{NO}_{2}\right)$, hydrocarbons (HCs), particulate matter (PM) and $90 \%-95 \%$ of the ambient carbon monoxide (CO) levels. Studies around the world have indicated that carbon monoxide is the most abundant pollutant per annum with practically $70 \%$ of all carbon monoxide gas produced solely by motor transport vehicles. Today, there is no doubt that the world has increasingly become urban (Aliyu \& Amadu, 2017) and human exposure to air pollutants is unavoidable in urban environment (Njoku et al., 2016). Therefore, studies with regards to air pollution have become very necessary to proffer solutions to the adverse effect it is having on the environment and the wellbeing of man. Studies carried out so far as regards vehicular emissions in Nigeria, were mostly focused on prevalence of the emissions at road intersections. However, little or no empirical study has been carried out in the Southeastern region to reveal the implication of vehicular emissions within the market environment. Especially bearing in mind, that a vast majority of them are engaged in one form of trading or another and so spend most of their time in the market place. Therefore, in order to close the research gap, this study seeks to assess the impact of vehicular emissions in markets places bearing in mind their importance in building the economy of the nation as any adverse health effects on the trader will have a serious consequence on the economic prosperity of the nation at large.

\section{The Study Area}

The study was conducted in Owerri Imo State, Southeast Nigeria. Owerri is made up of 30 markets comprising 17 open markets and 13 shopping centers/ supermarkets. The study area is Owerri metropolis which lies in the Central Business District (CBD) of Imo State. Owerri is the capital of Imo State, South East Nigeria. It is part of the three Local Government Areas: Owerri North, Owerri West and Owerri Municipal. Owerri urban is within the Owerri municipal It is located between $50^{\circ} 20^{\prime} \mathrm{N}, 60^{\circ} 55^{\prime} \mathrm{E}$ in the south-western corner and $50^{\circ} 34^{\prime} \mathrm{N}, 70^{\circ} 08^{\prime} \mathrm{E}$ in the northeastern corner meridian (Figure 1). Owerri Metropolis is characterized by influx of people and high volume of vehicular flows in and out of the area. Imo State has a population of about 3,934,899 (NPC, 2006). It lies within the humid tropics and is generally characterized by a high surface air temperature regime year-round (Ajiere et al., 2021). An annual mean rainfall of about $2000 \mathrm{~mm}$ to $2500 \mathrm{~mm}$ is experienced in the study area (Okonkwo \& Mbajiorgu, 2010). Owerri just like other location within the Imo state has two seasons, the rainy season which begins in April to October, while the dry season ranges from November to March (Ajiere et al., 2021) with its peak in July and September, and a short break in August. The dry season ranges from December to February with the influence of Harmattan felt between the months of December and January (Nwachukwu et al., 2018). Vegetation in the area ranges from light rainforest to Savannah with high trees particularly oil bean and palm trees around stream banks and swamps (Nwachukwu et al., 2018). Map of study area is depicted in Figure 1. 


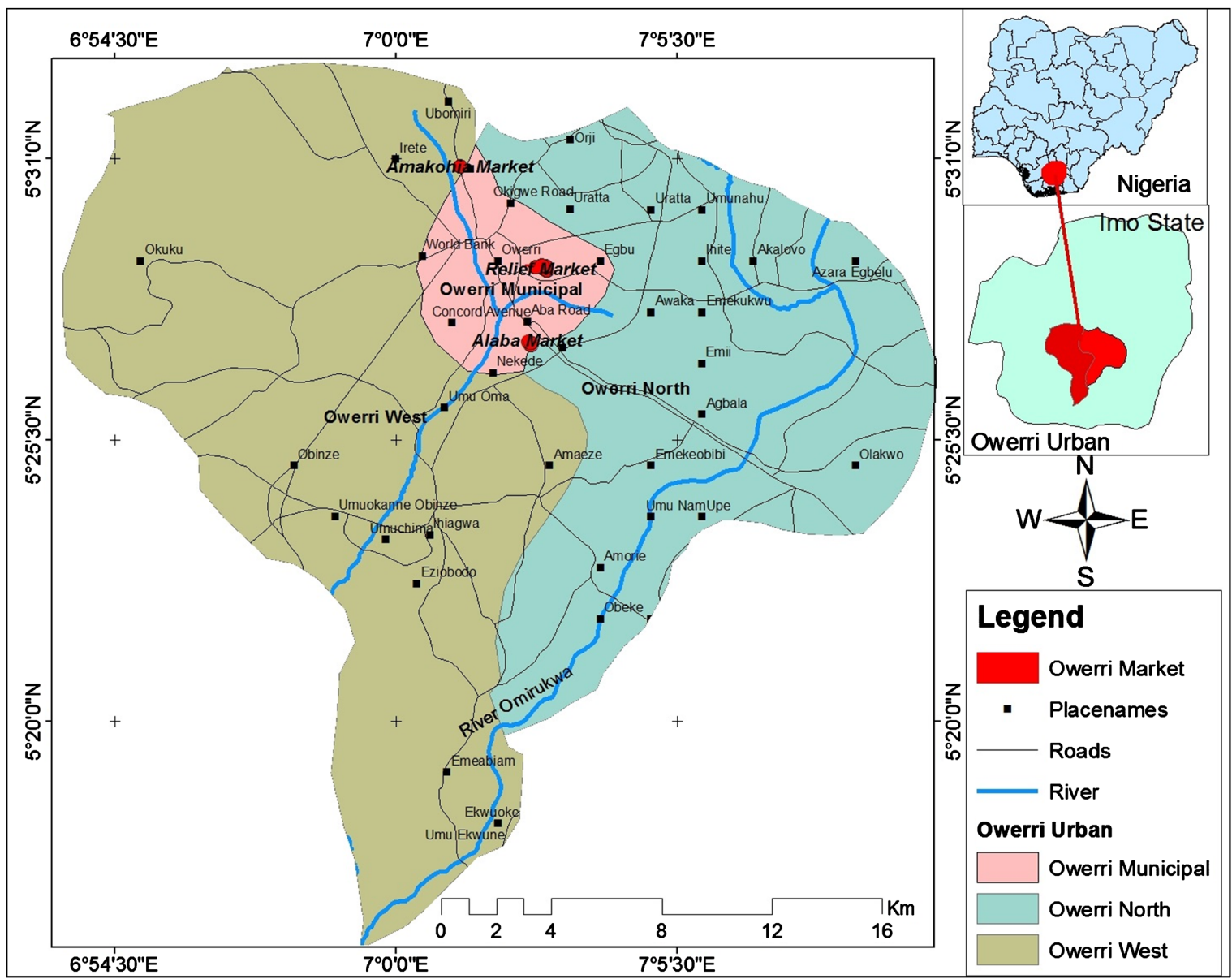

Figure 1. Study area showing sampled location.

\section{Materials and Methods}

This section deals with how data were collected and analyzed. Characteristics of sampled location are also included.

\subsection{Study Design}

This study was designed to assess the impact of vehicular emissions in selected markets in Owerri, Imo State of Nigeria The purposive method of sampling was adopted after careful consideration of all major markets in the study area; three markets were considered to be more congested during the day as a result of open assess to road junctions coupled with high density of vehicular movement, presence of offices, residential buildings, and human activities. These three markets in Owerri Urban were monitored and coded as SM1 to SM3. Air samples collected were analyzed for five air quality parameters during the morning hours $(8-10 \mathrm{am})$, and the afternoon hours $(2-4 \mathrm{pm})$. The time of response was less than 5 minutes. Measurements were carried out within 3 hours per sampling point and converted to a 1-hour mean. The reason for choosing these sampling times is due to the rush hours with their peak within the sampled time frame and each location was geo-referenced using a GPS device. The sampling was car- 
ried out in the month of June 2021 which fell within the rainy season. There was a total of 36 experimental runs for the five air pollution indices in the three locations monitored. The parameters monitored are $\mathrm{CO}, \mathrm{SO}_{2}, \mathrm{NO}_{2}$, and $\mathrm{PM} 10$ and PM 2.5 for 3 days. Aeroqual series 500 handheld air quality and gas monitor with interchangeable sensor heads; used for ambient air quality monitoring. Sensor heads used include $\mathrm{CO}, \mathrm{SO}_{2}, \mathrm{NO}_{2}, \mathrm{PM} 10$ and PM 2.5. The Series 500 air quality and gas sensor enable accurate real-time collection of air pollutants species, all in an ultra-portable handheld monitor. Each of these markets has different sample points of which $\mathrm{CO}, \mathrm{CO}_{2}, \mathrm{NO}_{2}, \mathrm{PM} 10$ and PM 2.5 were monitored. The markets with their coordinates are shown in Table 1.

\subsection{Sampling Location}

The impact of vehicular emission on ambient air quality was monitored in selected markets in Owerri and were designated as Sample Market One (SM1), Sample Market Two (SM2), and Sample Market Three (SM3). Each of these markets has different sample points of which $\mathrm{CO}, \mathrm{CO}_{2}, \mathrm{NO}_{2}$, and $\mathrm{PM} 10$ were monitored.

\section{Results and Discussion}

The regulatory framework put in place by government through Federal Environmental Protection Agency (FEPA) is limited to emission generated through stationary sources. In the absence of these standards, the data in this research work is compared with the NAAQS ambient air quality standards and WHO. The average emission estimates for air pollutant species generated from vehicular emissions both in the morning and afternoon periods at the different markets in Owerri for 3 different days displayed in Table 2 are discussed in this section.

The average concentrations of Carbon monoxide (CO) at Amakohia market ranged from $0.147-0.217 \mathrm{ppm}$ during the morning hours, and $0.150-0.187$ ppm in the afternoon. The values were less than the permissible limit (35 ppm) of NAAQS. At Relief market, it ranged from $0.030-0.047 \mathrm{ppm}$ during the morning hours and $0.020-0.030 \mathrm{ppm}$ in the afternoon. The values were also less than the permissible limit ( $35 \mathrm{ppm}$ ) of NAAQS. However, the highest range of $0.293-0.400 \mathrm{ppm}$ was recorded during the morning hours at Alaba market while during the afternoon hours, it ranged from $0.323-0.353 \mathrm{ppm}$. All the values were less than the permissible limit ( $35 \mathrm{ppm})$ of NAAQS and WHO. These

Table 1. Sampled location and coordinates.

\begin{tabular}{ccc}
\hline \multirow{2}{*}{ Sample Location } & \multicolumn{2}{c}{ Coordinates } \\
\cline { 2 - 3 } & Latitude & Longitude \\
\hline SM1: Amakohia Market & $5^{\circ} 30^{\prime} 51.4188^{\prime \prime} \mathrm{N}$ & $7^{\circ} 01^{\prime} 14.1744 " \mathrm{E}$ \\
SM2: Relief Market & $5^{\circ} 28^{\prime} 50.0808^{\prime \prime} \mathrm{N}$ & $7^{\circ} 02^{\prime} 48.5484 " \mathrm{E}$ \\
SM3: Alaba Market & $5^{\circ} 27^{\prime} 29.9448^{\prime \prime} \mathrm{N}$ & $7^{\circ} 02^{\prime} 34.1844^{\prime \prime} \mathrm{E}$ \\
\hline
\end{tabular}


Table 2. Sample location and air quality data for 3 days.

\begin{tabular}{|c|c|c|c|c|c|c|c|c|c|c|c|}
\hline \multirow{3}{*}{$\begin{array}{l}\text { Sample } \\
\text { locations }\end{array}$} & \multirow{3}{*}{$\begin{array}{c}\text { Sample } \\
\text { points } \\
\text { Time }\end{array}$} & \multicolumn{10}{|c|}{ Mean Concentration of emission level in the study area } \\
\hline & & \multicolumn{2}{|c|}{$\mathrm{CO}_{2}\left(\mathrm{mg} / \mathrm{m}^{3}\right)$} & \multicolumn{2}{|c|}{$\mathrm{NO}_{2}\left(\mathrm{mg} / \mathrm{m}^{3}\right)$} & \multicolumn{2}{|c|}{$\mathrm{CO}\left(\mathrm{mg} / \mathrm{m}^{3}\right)$} & \multicolumn{2}{|c|}{ PM $2.5\left(\mu \mathrm{g} / \mathrm{m}^{3}\right)$} & \multicolumn{2}{|c|}{$\operatorname{PM} 10\left(\mu \mathrm{g} / \mathrm{m}^{3}\right)$} \\
\hline & & $\begin{array}{l}\text { Morning } \\
\text { (7-10 am) }\end{array}$ & $\begin{array}{c}\text { Afternoon } \\
(2-5 \mathrm{pm})\end{array}$ & $\begin{array}{l}\text { Morning } \\
\text { (7-10 am) }\end{array}$ & $\begin{array}{c}\text { Afternoon } \\
(2-5 \mathrm{pm})\end{array}$ & $\begin{array}{l}\text { Morning } \\
\text { (7-10 am) }\end{array}$ & $\begin{array}{c}\text { Afternoon } \\
(2-5 \mathrm{pm})\end{array}$ & $\begin{array}{l}\text { Morning } \\
\text { (7-10 am) }\end{array}$ & $\begin{array}{c}\text { Afternoon } \\
(2-5 \mathrm{pm})\end{array}$ & $\begin{array}{l}\text { Morning } \\
\text { (7-10 am) }\end{array}$ & $\begin{array}{c}\text { Afternoon } \\
(2-5 \mathrm{pm})\end{array}$ \\
\hline \multirow{3}{*}{$\begin{array}{c}\text { SM1: } \\
\text { Amakohia } \\
\text { Market (day1) }\end{array}$} & SP1 & 1187 & 1145 & 0.121 & 0.100 & 0.14 & 0.100 & 0.014 & 0.010 & 0.035 & 0.030 \\
\hline & SP2 & 1187 & 1160 & 0.076 & 0.082 & 0.33 & 0.250 & 0.020 & 0.015 & 0.032 & 0.030 \\
\hline & SP3 & 1142 & 1160 & 0.121 & 0.082 & 0.18 & 0.180 & 0.019 & 0.014 & 0.014 & 0.021 \\
\hline \multirow{3}{*}{$\begin{array}{c}\text { SM1: } \\
\text { Amakohia } \\
\text { Market (day 2) }\end{array}$} & SP1 & 1177 & 1162 & 0.121 & 0.110 & 0.120 & 0.140 & 0.014 & 0.015 & 0.025 & 0.020 \\
\hline & SP2 & 1177 & 1162 & 0.115 & 0.120 & 0.280 & 0.155 & 0.018 & 0.018 & 0.028 & 0.029 \\
\hline & SP3 & 1120 & 1140 & 0.112 & 0.120 & 0.250 & 0.155 & 0.019 & 0.020 & 0.015 & 0.032 \\
\hline \multirow{3}{*}{$\begin{array}{c}\text { SM1: } \\
\text { Amakohia } \\
\text { Market (day 3) }\end{array}$} & SP1 & 1170 & 1140 & 0.120 & 0.090 & 0.110 & 0.180 & 0.014 & 0.012 & 0.020 & 0.014 \\
\hline & SP2 & 1180 & 1149 & 0.115 & 0.090 & 0.150 & 0.180 & 0.020 & 0.010 & 0.020 & 0.020 \\
\hline & SP3 & 1180 & 1155 & 0.120 & 0.090 & 0.180 & 0.200 & 0.018 & 0.015 & 0.024 & 0.020 \\
\hline \multirow{3}{*}{$\begin{array}{c}\text { SM2: Relief } \\
\text { Market (day 1) }\end{array}$} & SP1 & 1263 & 1187 & 0.143 & 0.115 & 0.01 & 0.03 & 0.029 & 0.020 & 0.207 & 0.200 \\
\hline & SP2 & 1254 & 1200 & 0.104 & 0.104 & 0.00 & 0.05 & 0.015 & 0.015 & 0.035 & 0.080 \\
\hline & SP3 & 1232 & 1230 & 0.131 & 0.130 & 0.08 & 0.00 & 0.026 & 0.019 & 0.149 & 0.100 \\
\hline \multirow{3}{*}{$\begin{array}{c}\text { SM2: Relief } \\
\text { Market (day 2) }\end{array}$} & SP1 & 1187 & 1230 & 0.530 & 0.216 & 0.010 & 0.020 & 0.022 & 0.020 & 0.078 & 0.104 \\
\hline & SP2 & 1236 & 1220 & 0.216 & 0.184 & 0.040 & 0.025 & 0.021 & 0.021 & 0.065 & 0.080 \\
\hline & SP3 & 1250 & 1245 & 0.146 & 0.180 & 0.090 & 0.015 & 0.025 & 0.025 & 0.051 & 0.095 \\
\hline \multirow{3}{*}{$\begin{array}{c}\text { SM2: Relief } \\
\text { Market (day 3) }\end{array}$} & SP1 & 1200 & 1190 & 0.145 & 0.140 & 0.040 & 0.030 & 0.015 & 0.010 & 0.180 & 0.150 \\
\hline & SP2 & 1263 & 1200 & 0.185 & 0.150 & 0.040 & 0.030 & 0.011 & 0.015 & 0.165 & 0.145 \\
\hline & SP3 & 1220 & 1200 & 0.150 & 0.149 & 0.045 & 0.029 & 0.015 & 0.019 & 0.170 & 0.120 \\
\hline \multirow{3}{*}{$\begin{array}{l}\text { SM3: Alaba } \\
\text { market (day 1) }\end{array}$} & SP1 & 1187 & 1200 & 0.082 & 0.085 & 0.350 & 0.350 & 0.011 & 0.015 & 0.015 & 0.020 \\
\hline & SP2 & 1146 & 1223 & 0.127 & 0.092 & 0.360 & 0.300 & 0.014 & 0.020 & 0.027 & 0.025 \\
\hline & SP3 & 1187 & 1245 & 0.107 & 0.107 & 0.390 & 0.380 & 0.019 & 0.019 & 0.037 & 0.032 \\
\hline \multirow{3}{*}{$\begin{array}{c}\text { SM3: Alaba } \\
\text { market (day 2) }\end{array}$} & SP1 & 1145 & 1880 & 0.127 & 0.110 & 0.380 & 0.350 & 0.015 & 0.015 & 0.014 & 0.014 \\
\hline & SP2 & 1170 & 1870 & 0.104 & 0.115 & 0.380 & 0.300 & 0.014 & 0.011 & 0.025 & 0.020 \\
\hline & SP3 & 1175 & 1875 & 0.098 & 0.120 & 0.400 & 0.320 & 0.019 & 0.015 & 0.030 & 0.022 \\
\hline \multirow{3}{*}{$\begin{array}{c}\text { SM3: Alaba } \\
\text { market (day 3) }\end{array}$} & SP1 & 1770 & 1145 & 0.115 & 0.095 & 0.290 & 0.360 & 0.010 & 0.015 & 0.015 & 0.015 \\
\hline & SP2 & 1180 & 1145 & 0.127 & 0.114 & 0.290 & 0.360 & 0.015 & 0.020 & 0.020 & 0.021 \\
\hline & SP3 & 1200 & 1170 & 0.130 & 0.098 & 0.300 & 0.340 & 0.019 & 0.018 & 0.028 & 0.028 \\
\hline & \multicolumn{3}{|c|}{ NAAQS } & \multicolumn{2}{|c|}{$\begin{array}{l}0.100 \text { PРM (188 } \\
\mu \mathrm{g} / \mathrm{m}^{3} \text { (1-Hour) }\end{array}$} & \multicolumn{2}{|c|}{$\begin{array}{c}35 \mathrm{ppm}\left(40 \mathrm{mg} / \mathrm{m}^{3}\right) \\
(1 \text {-hour })\end{array}$} & \multicolumn{2}{|c|}{$35 \mu \mathrm{g} / \mathrm{m}^{3}(24 \mathrm{Hr})$} & \multicolumn{2}{|c|}{$150 \mu \mathrm{g} / \mathrm{m}^{3}(24 \mathrm{Hr})$} \\
\hline & \multicolumn{3}{|c|}{ WHO, 2017} & \multicolumn{2}{|c|}{$\begin{array}{c}0.2-0.5 \mathrm{mg} / \mathrm{m}^{3} \\
(1 \mathrm{Hr})\end{array}$} & \multicolumn{2}{|c|}{$30 \mathrm{mg} / \mathrm{m}^{3}(1 \mathrm{Hr})$} & \multicolumn{4}{|c|}{$\begin{array}{c}\text { PM } 10\left(150 \mu \mathrm{g} / \mathrm{m}^{3} \text { for } 24 \mathrm{Hr}\right) \text { and PM } 2.5 \\
\left(75 \mu \mathrm{g} / \mathrm{m}^{3} \text { for } 24 \mathrm{Hr}\right) \text { Based on WHO } \\
\text { interim target } 1\end{array}$} \\
\hline
\end{tabular}


results imply that the market users are to a greater extent safe from the harm of carbon monoxide emitted from vehicles at the markets in Owerri metropolis both in the morning hours and in the afternoon at present. But regular monitoring needs to be done to ensure that the permissible limit is not exceeded.

The average concentrations of Carbon dioxide $\left(\mathrm{CO}_{2}\right)$ generated revealed that the concentration of Carbon dioxide $\left(\mathrm{CO}_{2}\right)$ at Amakohia market was in the range of 1158 - $1177 \mathrm{ppm}$ in the morning hours, and 1148 - $1155 \mathrm{ppm}$ in the afternoon. However, there is no national ambient air quality standard for $\mathrm{CO}_{2}$ concentration in the atmosphere, but literature survey according to (Adeyanju \& Manohar, 2017), shows that the average concentration of $\mathrm{CO}_{2}$ in ambient air stands at $314 \mathrm{ppm}$. This therefore implies that the average concentration of $\mathrm{CO}_{2}$ in Amakohia market is far above the ambient standard. At Relief market, it ranged from $1224-1250 \mathrm{ppm}$ in the morning, and $1197-1232 \mathrm{ppm}$ in the afternoon.

The values here are also above the standard limit of $314 \mathrm{ppm}$. At Alaba market, the concentration of $\mathrm{CO}_{2}$ ranged from $1163-1183 \mathrm{ppm}$ during the morning hours. However, the highest range (1153 - $1880 \mathrm{ppm})$ was recorded during afternoon hours. This was the highest recorded in the three markets. The elevated increase in $\mathrm{CO}_{2}$ in this market could be due to the serious traffic congestion and traffic intersection where vehicles were seen waiting for a long time. The implication of these results is that the market users are at a greater risk of suffering from the harm of carbon dioxide at the markets in Owerri metropolis.

However, the average concentrations of Nitrogen dioxide $\left(\mathrm{NO}_{2}\right)$ generated from vehicular emissions both in the morning and afternoon periods at the different markets showed that the concentration of Nitrogen dioxide $\left(\mathrm{NO}_{2}\right)$ in Amakohia market was in the range of $0.106-0.118 \mathrm{ppm}$ in the morning, and $0.088-0.117 \mathrm{ppm}$ in the afternoon. The range is higher than the permissible limit of $0.100 \mathrm{ppm}$ given by NAAQS. At Relief market, $\mathrm{NO}_{2}$ ranged from 0.104 $0.530 \mathrm{ppm}$ in the morning, and $0.104-0.216 \mathrm{ppm}$ in the afternoon which is above the permissible limit of $0.100 \mathrm{ppm}$ given by NAAQS the highest value of 0.530 was found at SP1 which had a high concentration of motorbikes. At Alaba market, the range was $0.105-0.124 \mathrm{ppm}$ in the morning and $0.095-0.115 \mathrm{ppm}$ in the afternoon. The values were higher than the permissible limit of $0.100 \mathrm{ppm}$ given by NAAQS. This could be due to the high increases in human activities as these markets are close to offices, residential areas that are characterized by high vehicular movement. The results indicate that market users stand the risk of being harmed by the adverse effect of nitrogen dioxide at the markets in Owerri metropolis. Hence, adequate mechanism should be put in place to decongest traffic around the markets so as to have a substantial reduction in the vehicular emissions.

The average concentrations of particulate matter (PM 2.5) generated showed that the concentration of particulate matter (PM 2.5) at Amakohia market were in the range of $0.014-0.020 \mu \mathrm{g} / \mathrm{m}^{3}$ during the morning hours and $0.010-0.020$ $\mu \mathrm{g} / \mathrm{m}^{3}$ in the afternoon. The values were far below the permissible limit of (150 $\left.\mu \mathrm{g} / \mathrm{m}^{3}\right)$. At Relief market, it ranged from $0.011-0.029 \mu \mathrm{g} / \mathrm{m}^{3}$ in the morning and 
$0.010-0.025 \mu \mathrm{g} / \mathrm{m}^{3}$ in the afternoon. At Alaba market, the range was 0.010 $\mu \mathrm{g} / \mathrm{m}^{3}$ to $0.019 \mu \mathrm{g} / \mathrm{m}^{3}$ during the morning hours and $0.011-0.020 \mu \mathrm{g} / \mathrm{m}^{3}$ during the afternoon period. The values were far below the permissible limit (150 $\mu \mathrm{g} / \mathrm{m}^{3}$ ) of NAAQS and WHO. The average concentrations of Particulate matter (PM 10) generated showed that the concentration of Particulate matter (PM 10) at Amakohia market were in the range of $0.021-0.027 \mu \mathrm{g} / \mathrm{m}^{3}$ during the morning hours and $0.018-0.027 \mu \mathrm{g} / \mathrm{m}^{3}$ in the afternoon. The values were far below the permissible limit $\left(150 \mu \mathrm{g} / \mathrm{m}^{3}\right)$ of NAAQS. At Relief, it ranged from 0.065 $0.172 \mu \mathrm{g} / \mathrm{m}^{3}$ in the morning and $0.093-0.138 \mu \mathrm{g} / \mathrm{m}^{3}$ in the afternoon. The values were far below the permissible limit $\left(150 \mu \mathrm{g} / \mathrm{m}^{3}\right)$ of NAAQS. At Alaba market, the range was 0.021 to $0.024 \mu \mathrm{g} / \mathrm{m}^{3}$ during the morning hours and $0.019-0.026$ $\mu \mathrm{g} / \mathrm{m}^{3}$ during the afternoon period. The values were far below the permissible limit $\left(150 \mu \mathrm{g} / \mathrm{m}^{3}\right)$ of NAAQS and WHO. The implication of these results is that the market users are to a greater extent safe from the harm of particulate matter at as the time of this study. More enlightenment campaign needs to be carried out to advise them on the best practices to adopt to continue to enjoy an atmosphere that is pollution free thereby improving livability in Owerri metropolis.

\section{Recommendations}

Therefore, the study recommends that government at all levels should ensure that air pollution monitoring stations are located in and around the markets for constant monitoring of air pollution. Also, adequate mechanism should be put in place to decongest traffic density in the city especially near markets so as to have a substantial reduction in vehicular emissions.

\section{Conclusion}

The study showed that the concentrations of carbon dioxide $\left(\mathrm{CO}_{2}\right)$ and nitrogen dioxide $\left(\mathrm{NO}_{2}\right)$ resulting from vehicular emissions were above the regulatory limits. However, the concentration of PM 10 and PM 2.5 were far below the permissible limit $\left(150 \mu \mathrm{g} / \mathrm{m}^{3}\right)$ of NAAQS and WHO. The low level of concentration of pollutants recorded within the study area may be attributable to the downwash of suspended particulates with the onset of the rainy season. The study, therefore, suggests that a similar study be conducted in the dry season to compare the concentration of pollutants within the study area.

The elevated values of $\mathrm{CO}_{2}$ and $\mathrm{NO}_{2}$ at the studied locations indicate the possible fuel combustion processes taking place in the markets of Owerri metropolis. Also, the result indicates a high risk of health problems in the markets; which may include lower concentrations in the arteries, reduction of oxygen needed by man, respiratory problems especially in children, lung inflammation, lowered immune system, vision impairment, global warming, etc.

\section{Conflicts of Interest}

The authors declare no conflicts of interest regarding the publication of this paper. 


\section{References}

Abam, F. I., \& Unachukwu, G. O. (2015). Vehicular Emissions and Air Quality Standards in Nigeria. European Journal of Scientific Research, 34, 550-560.

Achonu, G. (2017). Police Warm Imo Public against Use of Commercial Motorcycle. The Punch.

https://punchng.com/police-warn-imo-public-against-use-of-commercial-motorcycle

Adeyanju, A. A., \& Manohar, K. (2017). Effects of Vehicular Emission on Environmental Pollution in Lagos. Journal of Scientific Issues, Research and Essays, 5, 33-51.

Ajiere, S., Diagi, B. E., \& Edokpa, D. O. (2021). Impact of Climate Change Variability on Sustainable Agriculture in Imo State, Nigeria. Journal of Geographical Research, 4, 9-17. https://ojs.bilpublishing.com/index.php/jgr9-17

Aliyu, A. A., \& Amadu, L. (2017). Urbanization Cities, and Health: The Challenges to Nigeria, a Review. Annals of African Medicine, 16, 149-158.

https://doi.org/10.4103/aam.aam_1_17

Alozie, C. (2017). Okorocha Bans Keke Operators in Imo. The Vanguard. https://www.vanguardngr.com/2017/08/okorocha-bans-keke-operators-imo.

Chakraborty, P., Jayachandran, S., Padalkar, P., Sitlhou, L., Chakraborty, S., Kar, R., Bhaumik, S., \& Srivastava, M. (2020). Exposure to Nitrogen Dioxide $\left(\mathrm{NO}_{2}\right)$ from Vehicular Emission Could Increase the COVID-19 Pandemic Fatality in India: A Perspective. Bulletin of Environmental Contamination and Toxicology, 105, 198-204.

https://doi.org/10.1007/s00128-020-02937-3

Chukwuocha, N., Ogbenna, U., Ogugua, C., \& Emenike, N. (2016). Erosion Sensitivity Assessment of Communities in Owerri, Nigeria Using Geographic Information System and Revised Universal Soil Loss Equation Base Model. American Journal of Geographic Information System, 5, 55-67.

David, E., Bridget, D., \& Peace, N. (2019). An Assessment of Ground Level Criteria Pollutant Concentrations in Port Harcourt City. International Journal of Pollution Research, 2018, IJPR-111.

Etim, E. U. (2016). Air Pollution Emission Inventory along a Major Traffic Route within Ibadan Metropolis, Southwestern Nigeria. African Journal of Environmental Science and Technology, 10, 432-438. https://doi.org/10.5897/AJEST2016.2107

National Population Commission (NPC) (2006). Official Gazette, Legal Notice on Publication of the Details of the Breakdown of the National and State Provisional Total, 2006 Census (Notice No. 21, Vol. 94, pp. 1-26). Government of Federal Republic of Nigeria.

Houston, D., Wu, J., Ong, P., \& Winer, A. (2004). Structural Disparities of Urban Traffic in Southern California: Implication for Vehicle-related air Pollution Exposure in Minority and high-Poverty Neighborhoods. Journal of Urban Affairs, 26, 565-592. https://doi.org/10.1111/j.0735-2166.2004.00215.x

Ibe, F. C., Opara, A. I., Njoku, P. C., \& Alinnor, J. I. (2017). Ambient Air Quality Assessment of Orlu, Southeastern, Nigeria. Journal of Applied Sciences, 17, 441-457. https://doi.org/10.3923/jas.2017.441.457

Ipeaiyeda, A. R., \& Adegbooyega, D. A. (2017). Assessment of Air Pollutant Concentrations Near Major Roads in Residential, Commercial and Industrial Areas in Ibadan City, Nigeria. Journal of Health \& Pollution, 7, 11-21. https://doi.org/10.5696/2156-9614-7-13.11

Mauss, E. A. (2017). Childhood Lead Poisoning Prevention: The Tortuous Trail from Human Health Impact Assessment to Effective Environmental Policy. Environmental Im- 
pact Assessment Review, 14, 403-423. https://doi.org/10.1016/0195-9255(94)90010-8

Mmom, P. C., \& Essiet, U. (2014). Spatial-Temporal Variations in Urban Vehicular Emissions in Uyo City, Akwa Ibom State, Nigeria. Journal of Sustainable Development, 7, 272-281. https://doi.org/10.5539/jsd.v7n4p272

Muralikrishnan, R., Swarnalakshmi, M., \& Nakkeeran, E. (2014). Nanoparticle Membrane Filtration of Vehicular Exhaust to Reduce air Pollution: A Review. International Research Journal of Environment Sciences, 3, 82-86.

Ngele, S. O., \& Onwu, F. K. (2014). Assessment of Ambient Air Particulate Matter Level in Orlu Urban. Journal of Chemical and Pharmaceutical Research, 6, 871-875.

Njoku, P., Ibe, F. C., Alinnor, J., \& Opara, A. (2016). Seasonal Variability of Carbon Monoxide $(\mathrm{CO})$ in the Ambient Environment of Imo State, Nigeria. International Letters of Natural Sciences, 53, 40-52. https://doi.org/10.18052/www.scipress.com/ILNS.53.40

Nkwocha, A. C., Ekeke, I. C., Kamalu, C. I. O., Kamen, F. L., Uzondu, F. N., Dadet, W. P., \& Olele, P. C. (2017). Environmental Assessment of Vehicular Emission in Port-Harcourt City, Nigeria. International Journal of Environment, Agriculture and Biotechnology, 2, 906-911. https://doi.org/10.22161/ijeab/2.2.44

Nwachukwu, M. A., Alozie, C. P., \& Alozie, G. A. (2018). Environmental and Rainfall Intensity Analysis to Solve the Problem of Flooding in Owerri Urban. Journal of Environmental Hazard, 1, Article No. 107.

Ogungbe, A. S., Iginla, S. A., Alabi, A. A., \& Onori, E. O. (2019). Impact of Vehicular Emission on Air Pollution in Ojo Local Government Area of Lagos State, Nigeria. British Journal of Environmental Sciences, 7, 1-29.

Oguntoke, O., \& Yussuf, A. S. (2008). Air Pollution Arising from Vehicular Emissions and the Associated Human Health Problems in Abeokuta Metropolis, Nigeria. ASSET Series $A, 8,119-132$

Okonkwo, G. I., \& Mbajiorgu, C. C (2010). Rainfall Intensity Duration Frequency Analysis for Southeastern Nigeria. Agricultural Engineering International: CIGR Journal, 12, 22-30.

Okonkwo, S. I., Ezigbo, V. O., \& Okpala, K. O. (2019). Assessment of Automobiles Induced Pollution in an Urban Area: A Case Study of Owerri City Southeast, Nigeria. International Journal of Scientific and Engineering Research, 10, 31-33.

Okunola, O.J., Uzairu, A., Gimba, C. E., \& Ndukwe, G. I. (2012). Assessment of 31. Gaseous Pollutants along High Traffic Roads in Kano, Nigeria. International Journal of Environment \& Sustainability, 1, 1-15.

Olayinka, O. O., Adedeji, O. H., \& Ajibola, F. O. (2015). Monitoring Gaseous and Particulate Air Pollutants Near Major Highways in Abeokuta, Nigeria. Journal of Applied Science and Environmental Management, 19, 751-758. https://doi.org/10.4314/jasem.v19i4.23

Omenikolo, A. I., Uduma, C. I., Chinekeokwu, T., \& Abara, J. C. (2017). Assessment of Air Pollution Generated by Transport in Owerri, Southeast, Nigeria. Merit Research Journal of Environmental Science, 5, 9-17.

Roychowdhury, A., Nasim, U., Chandola, P., Shankar, A., Bajaj, A., Singh, K., Shrivastava, R., \& Das, G. (2016). Towards Clean Air in Nigerian Cities (pp. 1-50). Centre for Science and Environment.

Suh, H. H., Bahadori, T., Vallarino, J., \& Spengler, J. D. (2017). Criteria Air Pollutants and Toxic Air Pollutants. Environ Health Prospect, 108, 625-633. https://doi.org/10.1289/ehp.00108s4625

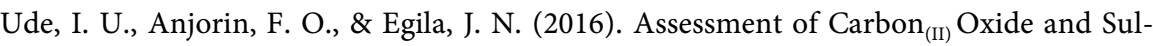


phur $_{(\mathrm{IV})}$ Oxide Emissions at Some Selected Traffic Areas in His Metropolis, North Central Nigeria. International Journal of Advanced and Innovative Research, 5, 6-14.

Ugbebor, J. N., \& LongJohn, I. P. (2018). Impact of Vehicular Traffic on Ambient Air Quality in Selected Junctions in Port Harcourt, Nigeria. Science World Journal, 13, 39-43.

Xie, X., Semanjski, I., Gautama, S., Tsiligianni, E., Deligiannis, N., Rajan, R. T., Pasveer, F., \& Philips, W. (2017). A Review of Urban air Pollution Monitoring and Exposure Assessment Methods. International Journal of Geo-Information, 6, Article No. 389. https://doi.org/10.3390/ijgi6120389

Zagha, O., \& Nwaogazie, I. L. (2015). Roadside Air Pollution Assessment in Port-Harcourt, Nigeria. Standard Research Journals, 3, 23-34. 